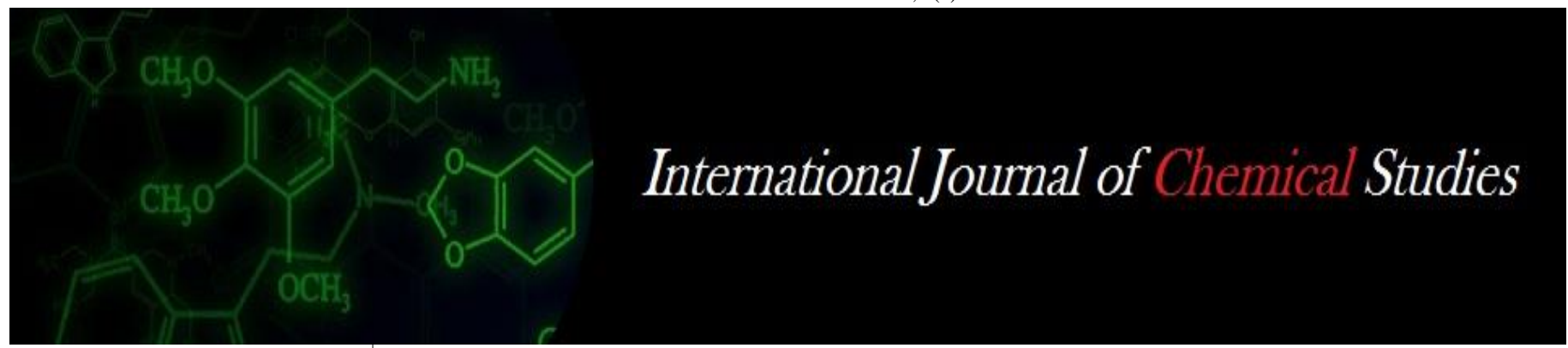

P-ISSN: 2349-8528

E-ISSN: 2321-4902

IJCS 2020; 8(1): 1585-1587

(C) 2020 IJCS

Received: 01-11-2019

Accepted: 03-12-2019

\section{SR Zanjare}

Seed Technology Research Unit, Seed Cell, Mahatma Phule Krishi Vidyapeeth, Rahuri,

Maharashtra, India

\section{YS Balgude}

Seed Technology Research Unit, Seed Cell, Mahatma Phule Krishi Vidyapeeth, Rahuri,

Maharashtra, India

Snehal S Zanjare

Seed Technology Research Unit, Seed Cell, Mahatma Phule Krishi Vidyapeeth, Rahuri,

Maharashtra, India

AV Suryawanshi

Seed Technology Research Unit, Seed Cell, Mahatma Phule Krishi Vidyapeeth, Rahuri,

Maharashtra, India

\section{VR Shelar}

Seed Technology Research Unit, Seed Cell, Mahatma Phule Krish Vidyapeeth, Rahuri,

Maharashtra, India
Corresponding Author SR Zanjare

Seed Technology Research Unit, Seed Cell, Mahatma Phule Krishi Vidyapeeth, Rahuri,

Maharashtra, India

\section{Detection of seed borne myco-flora associated with cowpea (Vigna unguiculata $\mathbf{L}$. Walp)}

\author{
SR Zanjare, YS Balgude, Snehal S Zanjare, AV Suryawanshi and VR \\ Shelar
}

DOI: https://doi.org/10.22271/chemi.2020.v8.i1w.8482

\section{Abstract}

The seed borne myco-flora of cowpea cv. Phule Vithai was examined by blotter method, agar plate method, deep freezing, 2-4 D method and Test tube water agar seedling symptom test as recommended by ISTA. A total of four species of fungi viz. Alternaria alternata, Aspergillus flavus, Aspergillus niger, Fusarium oxysporum, Penicillium spp. and Fusarium moniliforme were reported. Amongst the methods used for detection of seed borne fungi, the standard blotter paper method is more effective followed by agar plate method, 2, 4-D method, deep freeze blotter paper method and test tube water agar seedling symptom test.

Keywords: Cowpea, seed borne mycoflora, blotter paper method, agar plate method, deep freeze method, 2, 4-D method, test tube water agar seedling symptom test

\section{Introduction}

Pulses have been recognized as a major source of proteins $(20-35 \%)$ with required minerals and vitamins. Among the pulses, cowpea (Vigna unguiculata L. Walp) is a large seeded legume grown for its rich green pods, grains and stover by resource-poor farmers of under developed and developing countries of Africa and Asia. It is evident by the survey of literature showed both pathogenic and saprophytic fungi associated with cowpea seeds. Many workers have reported the association of Fusarium. oxysporium, F. equiseti, F. vertiloides, Aspergillus niger, A. flavus, Penicillium digitatum P. crycogenum, Rhizopus arrhizopus, and Rhizoctonia solani with seeds of cowpea crop (Kritzinger, 2003; Mogle and Maske, 2012; Makun et al., 2012) ${ }^{[7]}$. Hence the present study on detection of seed-borne mycoflora of cowpea was conducted to know the seed mycoflora associated with the cowpea seed.

\section{Material and Methods}

Collection of seed samples of cowpea

The seed sample of cowpea cv. Phule Vithai was collected from Pulses Improvement Project MPKV, Rahuri.

\section{Standard Blotter Paper Method}

Standard blotter method was used for the detection of seed borne fungi of cowpea. The 400 seeds were sown on three layers of pre-soaked moist blotter paper having $9 \mathrm{~cm}$ diameter. In each plate 10 seed were arranged, 9 seeds in the outer ring and one in the center of plastic plates. Petri plates were incubated at $20 \pm 2{ }^{\circ} \mathrm{C}$ giving alternate cycle of light and darkness (12 hours each) for 7 days. After incubation, the fungal colonies appeared on the seed surface were observed under stereoscopic binocular microscope. Wherever necessary, fungal growth was also be examined by research microscope. Seed mycoflora load in respect of number of colonies and types of fungi were recorded.

Agar Plate Method: Agar plate method is preferred mostly in plant pathological studies as it provides nutrients rich substrate for development of mycelial growth and sporulation of pathogen on seed, particularly for slow growing fungi. Four hundred infected seeds of cowpea were placed at the rate of 10 seeds per petri plate containing $20 \mathrm{ml}$ of two per cent water agar. 
Petri plates were incubated at $20 \pm 2{ }^{\circ} \mathrm{C}$ giving alternate cycle of light and darkness (12 hours each) for 7 days. After seven days of incubation, the fungal colony growth was examined under stereo-binocular microscope (Khare, 1996) ${ }^{[5]}$.

Deep Freeze Blotter Paper Method This method was developed by Limonard (1968) to detect slow growing pathogens. This method allows better growth of certain fungi as the imbibed seeds on moist blotters are killed by deep freezing and the enclosed nutrients in seed are utilized by fungi. Four hundred seeds were placed at the rate of 10 seeds per plate on moistened blotters in the way as described under standard blotter method. The petri plates were incubated at $20 \pm 2{ }^{\circ} \mathrm{C}$ for $24 \mathrm{hrs}$. under alternate cycles of $12 \mathrm{hrs}$. NUV light and darkness, for next 24 hours the plates were incubated at $-20{ }^{\circ} \mathrm{C}$ in darkness then kept back under original conditions for next five days. After eight days of incubation, the seed were examined under stereo-binocular microscope (Khare, 1996) ${ }^{[5]}$.

2, 4 - D blotter paper method: 2,4-D, is a herbicide retards seed germination and seedlings growth due to which the seeds are not displaced and the examination of fungi becomes easy. Four hundred seeds were placed at the rate of 10 seeds per petri plate with moistened blotter paper dipped in 0.2 per cent of sodium salt solution of 2,4 - dichloro phenoxy acetic acid. The petri plates were incubated at $20 \pm 2{ }^{\circ} \mathrm{C}$ giving alternate cycle of light and darkness (12 hours each) for 8 days After seven days of incubation, the fungal growth on seeds was examined by using stereo-binocular microscope (Khare, 1996) ${ }^{[5]}$.

\section{Test tube water agar seedling symptom test}

Collected cowpea seed samples were examined for seedling symptom test. Culture tubes $(100 \times 16 \mathrm{~mm})$ were filled with $10 \mathrm{ml}$ of 2 per cent water agar and solidified to have slight slant. Hundred seeds were placed individually in each tube and incubated at $20 \pm 2{ }^{\circ} \mathrm{C}$ with alternate cycles of $12 \mathrm{hrs}$ light and dark periods for 15 days. The cotton plug was removed after seedling reached to rim portion of the tube and observation was taken on symptom expressed in the seedling (Khare, 1996) ${ }^{[5]}$.

\section{Results}

Five different methods employed for detection of seed borne fungal infections presented in Table no.1.The results found that among the five methods, Standard blotter test with untreated seeds was found effective for detection of overall pathogens $(44.0 \%)$ followed by standard blotter test with pretreated seeds (26\%), Standard agar plate method (21.0\%), 2,4D blotter soak method (19.0\%),Test tube water agar seedling symptom test method $(15.0 \%)$ and Standard deep freeze blotter method $(10.0 \%)$. Standard blotter test with untreated seeds was found effective for detection of almost all the seedborne fungi associated with cowpea seeds except Fusarium oxysporum for which Standard deep freeze blotter method was found effective.

Domsch et al. (1980) ${ }^{[2]}$ reported that standard blotter method was the best method for the detection of cellulose decomposing fungi like Chaetomium and Fusarium species. Jovicevic (1980) ${ }^{[3]}$ suggested filter paper (blotting method) best for the routine analysis of seeds health because in agar plate method intrafungal antagonism becomes an issue. Niaz and Dawar, (2009) ${ }^{[10]}$ reported the deep-freezing method was best for the isolation of $F$. oxysporum. Sultana and Ghaffar (2009) ${ }^{[10]}$ found similar results and suggested blotter and deep-freezing methods best for the isolation of fungi.

The seed samples of cowpea cv Phule Vithai recorded six fungi (Table 1) viz., Aspergillus niger the infection ranges from 0 . 0 to $16.0 \%$, A. flavus 0.0 to $8.0 \%$, Fusarium oxysporum 3.0 to $16.0 \%$, Alternaria alternata, 0.0 to $5.0 \%$, Penicillium spp. 0.0 to $4.0 \%$, and $F$ monoliforme 0.0 to $3.0 \%$ in all methods employed for detection of seed borne fungal infections. Khare et al. (2016) ${ }^{[5]}$ reported the

Ahmed et al. (2007) ${ }^{[1]}$ reported the association of nine fungal species i.e. Aspergillus flavus, Aspergillus niger, Alternaria sp.,Cladosporium sp., Fusarium semitectum, Fusarium solani, Fusarium sp., Fusarium oxysporum and Penicillium sp. with the seeds of cowpea.

Mogle and Maske (2012) ${ }^{[8]}$ reported total 12 fungal species viz. Rhizoctonia solani, Aspergillus flavus, Cladosporium sp., Aspergillus niger, Penicillium sp., Fusarium oxysporum, Fusarium solani, Fusarium semitectum, Trichoderma viridie, Curvularia lunata, Mucor sp., and Verticillium sp. were associated with cowpea seeds.

Khare et al. (2016) ${ }^{[4]}$ found the association of total eight fungi from seeds of cowpea. These were Aspergillus flavus, A. niger, Cylindrocarpon sp., Fusarium equiseti, F. oxysporum, Penicillium chyrosogenum, Rhizopus oligosporus and $R$. stolonifer. Rhizopus spp. were dominant fungi recovered from seeds, followed by Penicillium, Aspergillus, Fusarium and Cylindrocarpon.

Table 1: Efficacy of different seed health testing methods for detection of seed-borne mycofloraof cowpea (Cv. Phule Vithai)

\begin{tabular}{|c|c|c|c|c|c|c|c|c|c|}
\hline \multirow{3}{*}{ S. No. } & \multirow{3}{*}{\multicolumn{2}{|c|}{ Detection methods }} & \multicolumn{7}{|c|}{ Pathogens associated (\%) } \\
\hline & & & \multicolumn{7}{|c|}{ Seed borne pathogens of significance } \\
\hline & & & \begin{tabular}{|c|}
$\begin{array}{c}\text { Aspergillus } \\
\text { niger }\end{array}$ \\
\end{tabular} & \begin{tabular}{|c|} 
Aspergillus \\
flavus
\end{tabular} & $\begin{array}{c}\text { Fusarium } \\
\text { oxysporum }\end{array}$ & $\begin{array}{c}\text { Alternaria } \\
\text { alternata }\end{array}$ & $\begin{array}{l}\text { Penicillium } \\
\text { spp. }\end{array}$ & \begin{tabular}{|c|} 
Fusarium \\
moniliforme
\end{tabular} & Total \\
\hline \multirow[b]{2}{*}{1.} & \multirow[b]{2}{*}{ Standard blotter test } & $\begin{array}{l}\text { Un-treated } \\
\text { Seeds }\end{array}$ & $16(23.57)$ & $8(16.42)$ & $8(16.42)$ & $5(12.92)$ & $4(11.49)$ & $3(9.90)$ & 44 \\
\hline & & $\begin{array}{c}\text { Pre-treated } \\
\text { seeds }\end{array}$ & $12(20.26)$ & $4(11.49)$ & $3(9.97)$ & $3(9.90)$ & $2(8.13)$ & $2(8.13)$ & 26 \\
\hline 2 & \multicolumn{2}{|c|}{ Standard Agar Plate } & $0(4.05)$ & $0(4.05)$ & $16(23.57)$ & $4(11.53)$ & $1(5.73)$ & $0(4.05)$ & 21 \\
\hline 3 & \multicolumn{2}{|c|}{ Standard deep freeze blotter } & $0(4.05)$ & $0(4.05)$ & $10(18.42)$ & $0(4.05)$ & $0(4.05)$ & $0(4.05)$ & 10 \\
\hline 4 & \multicolumn{2}{|c|}{ 2,4-D blotter soak } & $6(14.17)$ & $4(11.53)$ & $3(9.97)$ & $2(8.13)$ & $2(8.13)$ & $2(8.13)$ & 19 \\
\hline 5 & \multicolumn{2}{|c|}{$\begin{array}{c}\text { Test tube water agar seedling symptom } \\
\text { test }\end{array}$} & $3(9.97)$ & $3(9.97)$ & $5(12.92)$ & $3(9.97)$ & $1(5.73)$ & $0(4.05)$ & 15 \\
\hline \multicolumn{3}{|c|}{ S. E. \pm} & 0.13 & 0.24 & 0.15 & 0.28 & 0.24 & 0.28 & \\
\hline \multicolumn{3}{|c|}{$\mathrm{CD}$ at $5 \%$} & 0.38 & 0.73 & 0.47 & 0.84 & 0.73 & 0.84 & \\
\hline \multicolumn{3}{|c|}{ C.V. (\%) } & 2.05 & 5.12 & 2.33 & 2.03 & 3.81 & 3.52 & \\
\hline
\end{tabular}

(Figures in parentheses indicates arc sin transformed value) 


\section{Conclusion}

Among the five different methods employed for detection of seed borne fungal infections of cowpea cv Phule Vithai Standard blotter test with untreated seeds $(44.0 \%)$ was found the most effective for detection of overall pathogens. Six fungi species viz. Alternaria alternata, Aspergillus flavus, Aspergillus niger, Fusarium oxysporum, Penicillium spp. and Fusarium moniliforme were reported.

\section{References}

1. Ahmed O, Fawole OB, Balogun OS. Analysis of seed mycoflora in cowpea. Science edition. 2007; 14(1)2:7177.

2. Domsch KH, Gams W, Anderson TH. Compendium of Soil Fungi. London: Academic Press, 1980; 1:859.

3. Jovicevic B. Contribution to the knowledge of harmful mycoflora on seeds of wheat, maize and sunflower. Zastita Bilja. 1980; 31:101-119.

4. Khare KB, Loeto D, Wale K, Salani M, Seed-borne fungi of cowpea [Vigna unguiculata (L.) Walp] and their possible control in vitro using locally available fungicides in Botswana. International Journal of Bioassays. 2016; 5(11):5021-5024.

5. Khare MN. Methods to test seeds for associated fungi. Indian Phytopathology, 1996, 49.

6. Kritzinger QTAS, Cling AV, Marasas WFO, Rheedar JP. Mycoflora and Fumonisin mycotoxins associated with cowpea (Vigna unguiculata (L) Walp) Seeds. J of Agriculture and Food Chemistry. 2003; 51:2188-2192.

7. Makun HA, Anjorin ST, Abidoye AS, Rufai AR, Kabira YA. Incidence and botanical control of seed borne fungi of cowpea in Niger state, Nigeria APRN J Agriculture and Biological Sci. 2012; 7(8):654-658.

8. Mogle UP, Maske SR. Efficacy of bioagents and fungicides on seed mycoflora, germination and vigour index of cowpea. Science Research Reporter. 2012; 2(3):321-326.

9. Niaz I, Dawar S. Detection of seed borne mycoflora in maize (Zea mays L.). Pak. J Bot. 2009; 41(1):443-451.

10. Sultana N, Ghaffar A. Seed borne fungi associated with bottle gourd. (Lagenaria siceraria (Mol.) Standl. Pak. J Bot. 2009; 41(1):435-442. 